\title{
Annealing effect of micro-alloying on the microstructure and properties of $\mathrm{Cu}-10 \mathrm{Zn}$ alloy
}

\author{
Wei Chen ${ }^{1,2, *}$, Jiarui $\mathrm{Hu}^{1}$, Yi Xie ${ }^{1}$, Hengyi Zhou ${ }^{1}$, Chao Feng ${ }^{1}$, Yu Bo ${ }^{3}$, Zhu Xiao ${ }^{2, *}$ \\ ${ }^{1}$ State Grid Hunan Electric Power Company Limited Research Institute, Changsha 410007, China \\ ${ }^{2}$ School of Materials Science and Engineering, Central South University, Changsha 410083, PR China \\ ${ }^{3}$ State Grid Hunan Electric Power Company Limited, Changsha 410007, China
}

\begin{abstract}
The effect of $\mathrm{Fe}$ and $\mathrm{P}$ (Ni and $\mathrm{Si}$ ) on the microstructure and properties of $\mathrm{Cu}-10 \mathrm{Zn}$ alloys has been investigated using hardness test, electrical conductivity measurement, optical microscopy and transmission electron microscopy. $\gamma$-Fe precipitates formed during the aging process, but there is almost no effect of precipitation strengthening on the $\mathrm{Cu}-\mathrm{Zn}-\mathrm{Fe}-\mathrm{P}$ alloy and sparsely Fe3P precipitates existed in the matrix. After homogenization treatment at $900^{\circ} \mathrm{C}$ for $2 \mathrm{~h}$, hot rolling by $80 \%$, cold rolling by $80 \%$, and ageing treatment at $400^{\circ} \mathrm{C}$ for $30 \mathrm{~min}, \mathrm{Cu}-\mathrm{Zn}-\mathrm{Ni}$-Si alloy obtained good combinations of hardness $(219.8 \mathrm{HV})$ and electrical conductivity(28.2\%IACS). Ni2Si precipitates formed during aging process and the crystal orientation relationship between matrix and precipitates is: $(200)_{\alpha}\left\|(100)_{\delta},[100]_{\alpha}\right\|[010]_{\delta}$, Compared with $\mathrm{Cu}-\mathrm{Zn}-\mathrm{Fe}-\mathrm{P}, \mathrm{Cu}-\mathrm{Zn}-\mathrm{Ni}-\mathrm{Si}$ has finer grains, and the precipitation strengthening effect is more obvious.
\end{abstract}

\section{Introduction}

$\mathrm{Cu}-\mathrm{Zn}$ alloys are a typical solid solution strengthening copper alloy [1]. They have been widely used for industrial products, such as connectors, valves, pipes, radiators and so on, due to its good electrical conductivity, thermal conductivity, low cost and easy to manufacture [2-3]. However its low performance limited their application. With the rapid development of the machinery manufacturing industry, its corresponding performance requirements are also increasing [4-5]. In the past few years, many researchers have made great efforts to take micro-alloying, deformation and heat treatment to improve the strength, conductivity and softening resistance of the copper-based alloys [5-6]. But there are few reports on the effect of performance of $\mathrm{Cu}-\mathrm{Zn}$ alloys can be found that most previous studies were focused on their deformation [7-8]. It found that the comprehensive performance of the alloy can be obviously improved by codoping $\mathrm{Fe} / \mathrm{P}$ or $\mathrm{Ni} / \mathrm{Si}$ in the copper matrix. Thus the same effect is expected to obtained in $\mathrm{Cu}-\mathrm{Zn}$ matrix. In this paper, $\mathrm{Cu}-\mathrm{Zn}-\mathrm{Fe}-\mathrm{P}$ (Ni-Si) alloys have been designed and investigated, with an aim to reveal the effect of micro-alloying on the microstructure and properties of $\mathrm{Cu}-\mathrm{Zn}$ alloys in detail to explore a new strategy to develop new complex brass alloys.

\section{Materials and experimental procedure}

Electrolytic copper, pure zinc, pure nickel, pure silicon, and pure ferrum were prepared and melted in a intermediate frequency furnace, and then cast in an iron mold. After surface defects were removed, all the casting ingots were homogenized at $900^{\circ} \mathrm{C}$ for $2 \mathrm{~h}$, then rapidly hot rolled from a thickness of $30 \mathrm{~mm}$ to $5 \mathrm{~mm}$, followed by quickly quenching into cold water. The hot-rolled plate was planed on both sides to remove surface defects, and then cut into small samples. Samples were cold rolled with $80 \%$ reduction at room temperature, followed by isothermal aging at different temperatures for various time in a salt-bath furnace.

Vickers hardness (HV) was carried out on HV-5 type microhardness tester with $1-2 \mathrm{~kg}$ load and $10 \mathrm{~s}$ loading time according to ASTM E384-11 Standard [9]. Electrical conductivity was measured at $20^{\circ} \mathrm{C}$ using a Eddy Conductivity Instrument, taking the average of 7 values to minimize errors. The specimens were etched in a solution containing $\mathrm{FeCl}$, hydrochloric acid and alcohol and optical observations were made on a Leica optical microscope. Transmission electron microscopy (TEM) samples were prepared by double jet electropolishing techniques using a $20 \%$ nitric acid in methanol solution at about $-35^{\circ} \mathrm{C}$. TEM observations were carried out on a TECNAI G2 F20 transmission electron microscope with operation voltage of $200 \mathrm{kV}$.

\section{Results and discussion}

\subsection{Thermo-mechanical treatment}

\footnotetext{
*Corresponding author's e-mail: 59839696@qq.com
} 
The OM images of as-cast alloy are shown in Fig.1. As shown in Fig.1a, it shows that $\mathrm{Cu}-\mathrm{Zn}-\mathrm{Fe}-\mathrm{P}$ alloy is mainly composed of $\alpha-\mathrm{Cu}$ matrix, faint dendrites in the grains can be found
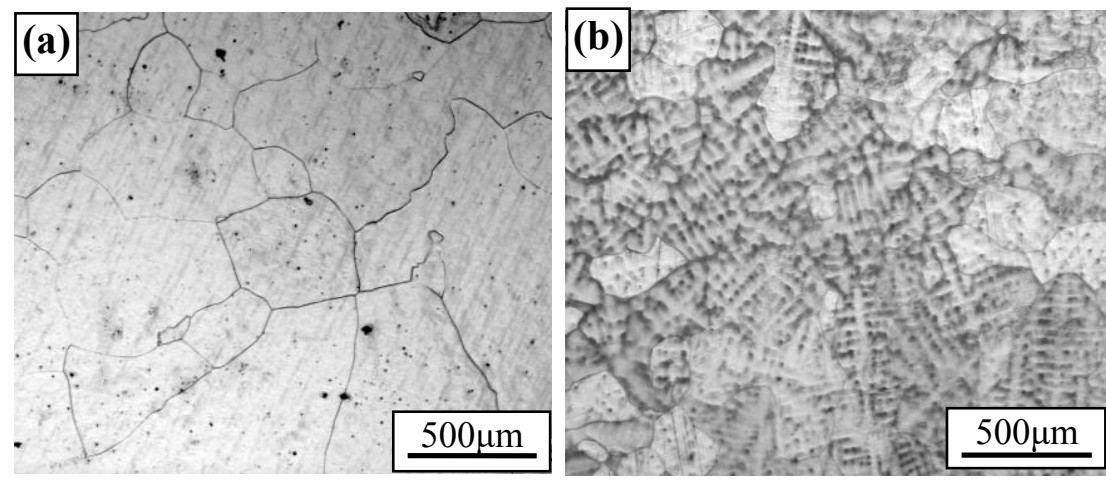

Figure 1. Optical microstructure of designed alloys. (a)as-cast $\mathrm{Cu}-\mathrm{Zn}-\mathrm{Fe}-\mathrm{P}$ alloy; (b)as-cast Cu-Zn-Ni-Si alloy

and the average grain size is about $550 \mu \mathrm{m}$. Fig.1b shows the OM image of $\mathrm{Cu}-\mathrm{Zn}-\mathrm{Ni}-\mathrm{Si}$, lots of dendrites appeared amongst the grians and the average grain size of the alloy is only about $260 \mu \mathrm{m}$ indicating the grains of as-cast $\mathrm{Cu}-\mathrm{Zn}$ alloy can be effectively refined with addition of $\mathrm{Ni}$ and $\mathrm{Si}$.

\subsection{Effect of small alloying additions on hardness and resistivity of the alloy during aging treatment}

The hot rolled-quenched and cold rolled samples were aged at different temperatures for various time in a

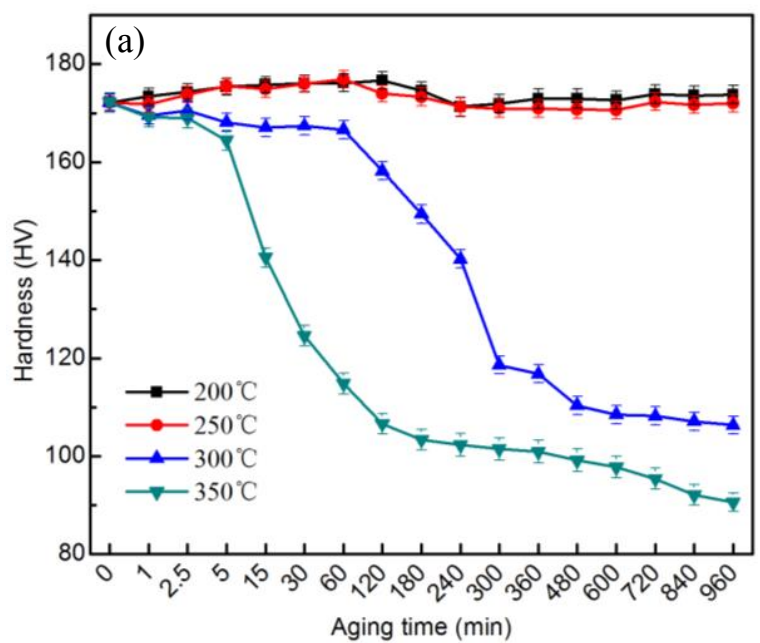

salt-bath furnace. Fig. 2 shows the variation of hardness and electrical conductivity of $\mathrm{Cu}-\mathrm{Zn}-\mathrm{Fe}-\mathrm{P}$ alloys after ageing treatment at $200^{\circ} \mathrm{C}, 250^{\circ} \mathrm{C}, 300^{\circ} \mathrm{C}$ and $350^{\circ} \mathrm{C}$. The hardness of $\mathrm{Cu}-\mathrm{Zn}-\mathrm{Fe}-\mathrm{P}$ increased slowly as aging treatment below $300^{\circ} \mathrm{C}$ with duration, but it descreased rapidly with aging time when the aging temperature was above $300^{\circ} \mathrm{C}$. These results were very similar to that of $\mathrm{Cu}-\mathrm{Zn}$ alloy. The corresponding electrical conductivities increased continuously and more and more rapidly with the aging temperature raised which was different from that of $\mathrm{Cu}-\mathrm{Zn}$ alloy. Hence it can be inferred that some precipitation are produced during the aging precess.

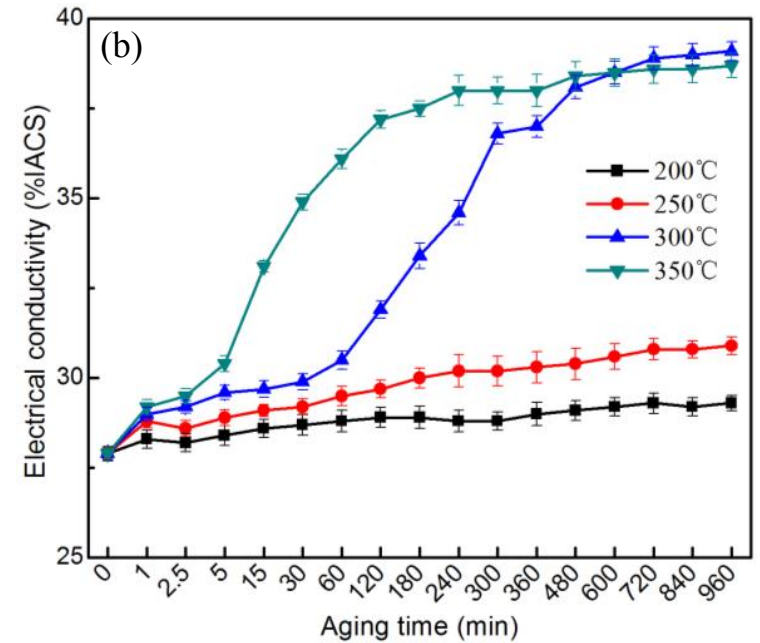

Figure 2. Variation of hardness and electrical conductivity of $\mathrm{Cu}-\mathrm{Zn}-\mathrm{Fe}-\mathrm{P}$ alloys during aging treatment: (a) hardness;(b) electrical conductivity

Fig. 3 shows the variation of hardness and electrical conductivity of $\mathrm{Cu}-\mathrm{Zn}-\mathrm{Ni}-\mathrm{Si}$ alloys after ageing treatment at $350^{\circ} \mathrm{C}, 400^{\circ} \mathrm{C}, 450^{\circ} \mathrm{C}$ and $500^{\circ} \mathrm{C}$. The higher the aging temperature is, the lower the peak hardness value of the alloy reaches, and the peak aging time occurs. The electrical conductivity increased with aging time at different temperature. The electrical conductivity raised more rapidly at the initial stage with aging temperature rising. The peak hardness values of $\mathrm{Cu}-\mathrm{Zn}-\mathrm{Ni}-\mathrm{Si}$ alloys were $224.5 \mathrm{HV}, 219.8 \mathrm{HV}, 215.2 \mathrm{HV}$, 209.3HV as aging treatment at $350^{\circ} \mathrm{C}$ for $120 \mathrm{~min}, 400^{\circ} \mathrm{C}$ for $30 \mathrm{~min}, 450^{\circ} \mathrm{C}$ for $5 \mathrm{~min}$ and $500^{\circ} \mathrm{C}$ for $1 \mathrm{~min}$ respectively. And the corresponding electrical conductivities were 26.9\%IACS, 28.2\%IACS, 25.7\%IACS and 25.2\%IACS, respectively. 

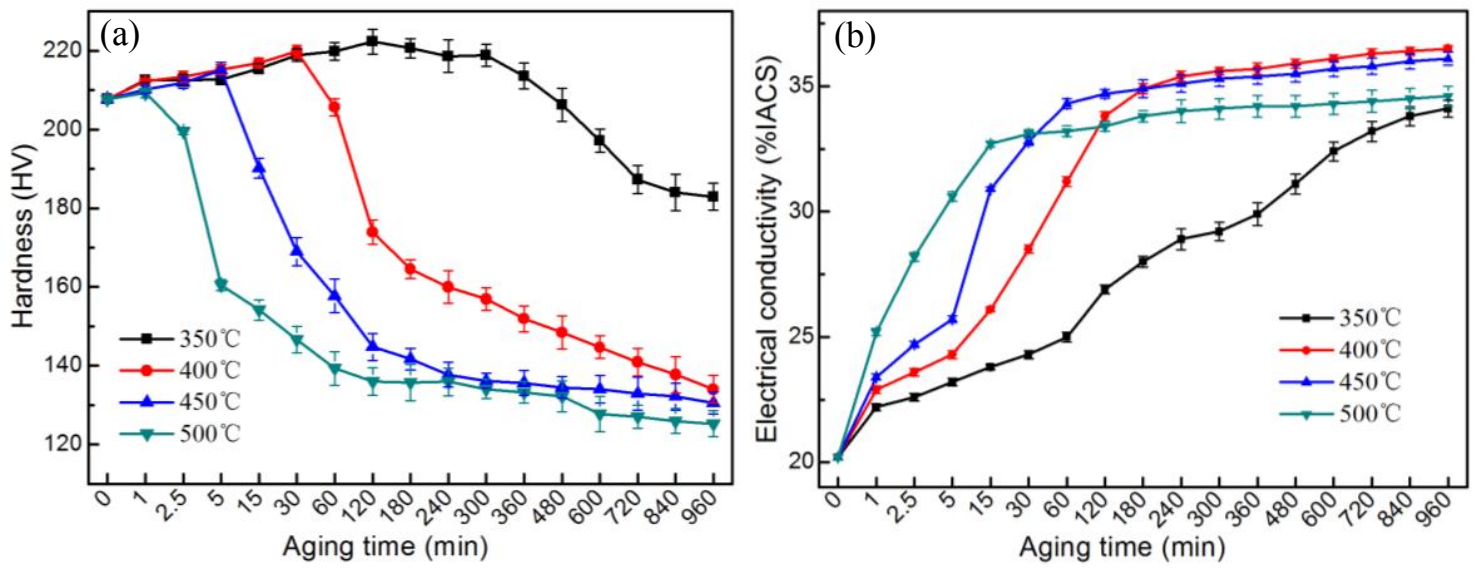

Figure 3. Aging behavior of hardness and electrical conductivity of $\mathrm{Cu}-\mathrm{Zn}-\mathrm{Ni}-\mathrm{Si}$ alloys.

(a) hardness;(b) electrical conductivity

\section{Discussion}

$\mathrm{Cu}-\mathrm{Fe}$ binary alloy phase diagram shows that the solubility of $\mathrm{Fe}$ in Copper decreases with the temperature down $\left(3.5 \%\right.$ at $1050^{\circ} \mathrm{C}, 1.4 \%$ at $900^{\circ} \mathrm{C}$ and only $0.0004 \%$ blow $\left.300^{\circ} \mathrm{C}\right)$. While the temperature decreasing to a certain extent, $\gamma-\mathrm{Fe}$ can precipitate out from the supersaturated sold solution which can strengthen the alloys. Fig.4 shows TEM micrographs, corresponding energy dispersive X-ray spectrometry (EDS) and selected-area diffraction patterns(SADP) of cold rolled $\mathrm{Cu}-\mathrm{Zn}-\mathrm{Fe}-\mathrm{P}$ alloy aged at $450^{\circ} \mathrm{C}$ for $10 \mathrm{~h}$. The TEM bright-field (BF) micrograph and the

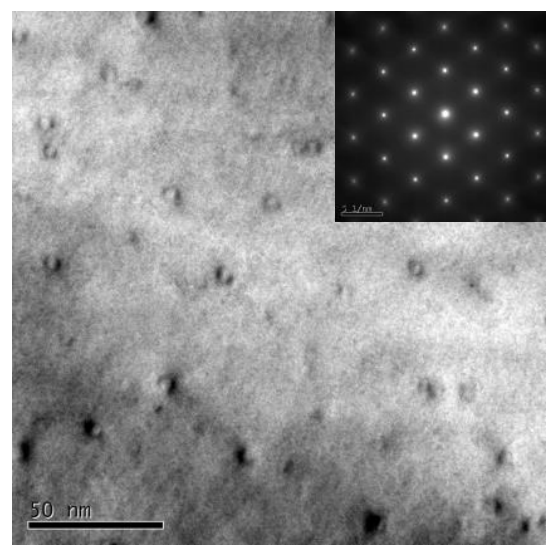

Fig.4. TEM micrographs and SADP with electron beam parallel to [110 $]_{\alpha}$ of $\mathrm{Cu}-\mathrm{Zn}-\mathrm{Fe}-\mathrm{P}$ alloys that underwent solution treatment and cold rolling by $80 \%$ and followed by ageing treatment at $450^{\circ} \mathrm{C}$ for $10 \mathrm{~h}$

corresponding SADP of the $\mathrm{Cu}-\mathrm{Zn}-\mathrm{Fe}-\mathrm{P}$ sample with electron beam parallel to [110] $\alpha$. was shonwn in Fig.5a. Nanoscale $\gamma$-Fe particles with horseshoe-shaped strain-field contrast are dispersed in the sample. This indicates that the $\gamma$-Fe prepitates are coherent with the matrix and the length of zero-contrast line is less than $2 \mathrm{~nm}$. There is no second phase diffraction spots can be found that only copper matrix diffraction spots exist. This mainly because both $\mathrm{Cu}$ and $\gamma$-Fe have face center cubic structure with structure parameters $\mathrm{a}=0.3615 \mathrm{~nm}$ and $\mathrm{a}^{\prime}=0.3590 \mathrm{~nm}$ respectively, and the lattice misfit of them is only $0.7 \%$ [10]. Thus the SPAD of $\gamma$-Fe would be coincident with that of copper due to this fully coherent effects.

On the basis of the above hardness curve, it reveals that $\gamma$-Fe precipitated out from $\mathrm{Cu}-\mathrm{Zn}$-Fe-P alloy during aging treatment. but the hardening effect was very faint. Solute segregation to dislocation, analogous to the formation of Cottrell atmospheres in interstitial solid solutions, was primarily responsible for anneal hardening phenonenon of the $\mathrm{Cu}-\mathrm{Zn}$ alloy [11]. While the precipitation strengthen by coherent $\gamma$-Fe precipitates was the main strengthening mechanism to $\mathrm{Cu}-\mathrm{Zn}-\mathrm{Fe}-\mathrm{P}$ alloy. As for the electrical conductivity of $\mathrm{Cu}-\mathrm{Zn}-\mathrm{Fe}-\mathrm{P}$ alloy, it was highly increased due to the precipitation of $\gamma$-Fe, espercially at high temperature (above $300^{\circ} \mathrm{C}$ ). As we known, alloy softening occurs at high temperatures is primarily due to two reasons as follow. One is the size of precipitates increased with the aging time that make the precipitation strengthening effect down, the other is the soft effect of recovery and recrystalliztion. As seen from the hardness curves of $\mathrm{Cu}-\mathrm{Zn}-\mathrm{Fe}-\mathrm{P}$ alloy above, the precipitation strengthening of $\mathrm{Cu}-\mathrm{Zn}$ alloy with addition of iron and phosphorus is very tiny that is even less than the soft effect of recovery and recrystalliztion.

TEM micrographs and selected-area diffraction 
patterns with electron beam parallel to [001] $\alpha$ of cold rolled $\mathrm{Cu}-\mathrm{Zn}-\mathrm{Ni}-\mathrm{Si}$ alloy aged at $400^{\circ} \mathrm{C}$ for $16 \mathrm{~h}$ are shown in Fig. 5 .

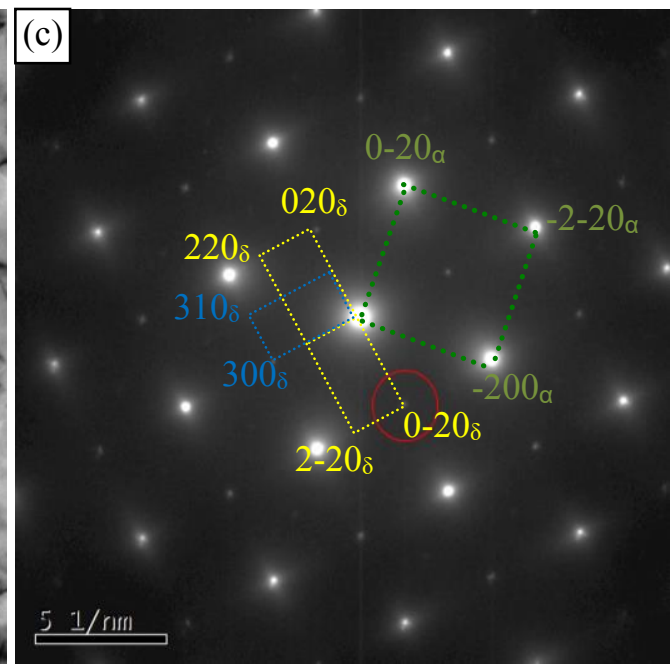

Figure 5. TEM micrographs and SADPs of $\mathrm{Cu}-\mathrm{Zn}-\mathrm{Ni}$-Si alloys that under ageing treatment at $400^{\circ} \mathrm{C}$ for $16 \mathrm{~h}$ :(a) bright-field micrograph; (b) beam direction of SADP along $[001]_{\mathrm{Cu}}$

With the aging at $400^{\circ} \mathrm{C}$ for $16 \mathrm{~h}$, great adeals of rod-shaped and disc-shaped precipitates were found in the bright-field of $\mathrm{Cu}-\mathrm{Zn}-\mathrm{Ni}-\mathrm{Si}$ alloy as shown in Fig. 5a. The corresponding SADP with electron beam parallel to $[100] \alpha$ of the Fig. 6 b was shown in Fig. 5b.

The rod-shaped precipitates mainly have two directions perpendicular to each other, while the disc-shaped precipitates seem to be embedded in the matrix. The diffraction spots from $\delta$-Ni2Si precipitates appeared clearly, and the indexation result indicated that the crystal orientation relationship between matrix and $\delta-\mathrm{Ni}_{2} \mathrm{Si}$ precipitates is $(001) \mathrm{m}\|(001) \mathrm{p},[110] \mathrm{m}\|[100] \mathrm{p}$.

On the basis of the foregoing, it appears that $\mathrm{Cu}-\mathrm{Zn}-\mathrm{Ni}-\mathrm{Si}$ alloy has a pronounced aging response, and good combinations of hardness and electrical conductivity can be obtained under aging treatment at $400^{\circ} \mathrm{C}$ for $30 \mathrm{~min}$. This demonstrates the precipitation strengthening effect of addition of $\mathrm{Ni}$ and $\mathrm{Si}$ is more valid and effective contrast to addtion of $\mathrm{Fe}$ and $\mathrm{P}$.

\section{Conclusions}

1. Solute segregation to dislocation was primarily responsible for anneal hardening phenonenon of the $\mathrm{Cu}-\mathrm{Zn}$ alloy. The addition of iron and phosphorus can not refine the grains of $\mathrm{Cu}-\mathrm{Zn}$ alloy effectively. $\gamma$-Fe precipitates formed in the $\mathrm{Cu}-\mathrm{Zn}-\mathrm{Fe}-\mathrm{P}$ alloy during the aging process, but very week effect of precipitation strengthening on the alloy can be obtained.

2 . The addition of nickel and silicon refines the grains of $\mathrm{Cu}-\mathrm{Zn}$ alloy effectively. $\delta$-Ni2Si precipitates formed in the $\mathrm{Cu}-\mathrm{Zn}-\mathrm{Ni}-\mathrm{Si}$ alloy during aging treatment which can make strongly precipitation strengthening effect. The crystal orientation relationship between the matrix and precipitates is: $(001) \mathrm{m}\|(001) \mathrm{p},[110] \mathrm{m}\|[100] \mathrm{p}$.

3. After homogenization treatment at $900^{\circ} \mathrm{C}$ for $2 \mathrm{~h}$, hot rolling by $80 \%$, cold rolling by $80 \%$, and ageing treatment at $400^{\circ} \mathrm{C}$ for $30 \mathrm{~min}, \mathrm{Cu}-\mathrm{Zn}-\mathrm{Ni}-\mathrm{Si}$ alloy obtained good combinations of hardness $(219.8 \mathrm{HV})$ and electrical conductivity $(28.2 \% \mathrm{IACS})$.

\section{References}

1. Chen W, Jia Y, Yi J, et al. Effect of addition of Ni and $\mathrm{Si}$ on the microstructure and mechanical properties of $\mathrm{Cu}-\mathrm{Zn}$ alloys. J MATER RES, 2017:1-9.

2. Xia Z, Szklarska-Smialowska Z. Pitting of Admiralty Bras. Corros. Sci., 1990, 46(1):85-88.

3. Plewes J T,Loiacono D N.Free-cutting copper alloys contain no lead. Adv. Mater. Processes, 1991,140(4):23-27.

4. CAI W ei, RAO Ke, LI Li. Grains refinement and the microstructure and properties of H65 brass strip. Special Casting and Nonferrous Alloys, 2007, 27(9): 728-730.

5. Mapelli C. Venturini R. Dependence of the mechanical properties of an tl brass on the microstructural features induced by hot extrusion. Scripta Mater., 2006, 54(6): 1169-1173.

6. Lei Q, Li Z, Dai C, et al. Effect of aluminum on microstructure and property of $\mathrm{Cu}-\mathrm{Ni}-\mathrm{Si}$ alloys. Mater. Sci. Eng., A, 2013, 572(6):65-74.

7. Liu Z Y, Liang G X, Wang E D, et al. The effect of cumulative large plastic strain on the structure and properties of a $\mathrm{Cu}-\mathrm{Zn}$ alloy. Mater. Sci. Eng., A (Structural Materials Properties Microstructure \& Processing), 1998, 242(1-2):137-140.

8. Peng K, Zhang Y, Shaw L L, et al. Microstructure dependence of a $\mathrm{Cu}-38 \mathrm{Zn}$ alloy on processing conditions of constrained groove pressing. Acta Mater., 2009, 57(18): 5543-5553. 
9. ASTM Standard E384-11. Standard test method for knoop and Vickers hardness of materials. West Conshohocken (PA): ASTM International; 2011.

10. Dong Q, Shen L, Feng C, et al. Study of the coarsening and hardening behaviors of cocherent
$\gamma$-Fe particles in $\mathrm{Cu}-2.1 \mathrm{Fe}$ alloy. ACTA METALL SIN (Chinese Edition), 2014, 50(10):1224-1230.

11. Vitek J M, Warlimont $H$. The mechanism of anneal hardening in dilute copper alloys. Metall. Trans. A, 1979, 10(12):1889-1892. 